\title{
ROZHODOVACIE KRITÉRIA PRI VÝBERE POSKYTOVATELA POŠTOVÝCH SLUŽIEB
}

\author{
Lucia Madleňáková*
}

\section{Úvod}

Modely, ktoré hodnotia nákupné správanie sa zákazníka, sa mnohokrát sústred’ujú na tzv. ,priemerné typy“ a to predovšetkým z dôvodu jednoduchosti. Vytvorit' však optimálnu ponuku a odhadnút' kritéria výberu poskytovatel'a služby je náročné a často krát vôbec nezodpovedá modelovým typom nakupujúceho. Dôvody tejto situácie sú jasné. Nie je možné priemerovat' zákazníka a zovšeobecňovat' jeho nákupné zvyklosti pre jednotlivé segmenty produktov a služieb. Pre každý typ zákazníka existuje iná účinná metóda pre tvorbu ponuky osobitne v každom a jednom segmente služieb.

\section{Všeobecné nákupné rozhodovacie kritéria}

Pochopenie zákazníckeho správania sa, preferencií a požiadaviek je možné len na základe dôkladnej analýzy faktorov, ktoré na zákazníka pri výbere poskytovatel'a služby či samotného produktu vplývajú. Nájdenie kl’účových faktorov rozhodovania sa zákazníka je možné na základe identifikácie odpovedí na základné otázky týkajúce sa správania napr.: KTO je dôležitý na to, aby rozhodol o kúpe? PREČO zákazníci nakupujú? AKÉ kritéria výberu používajú? KDE zákazníci nakupujú? KEDY zákazníci nakupujú? [2]

Nákupné zvyklosti súvisia s rozhodnutiami potenciálneho zákazníka, ktorého môžeme označit' ako individuálneho, alebo skupinového (ak nakupujúcim je firma). Nákupné zvyklosti individuálneho zákazníka súvisia so vznikom jeho individuálnych potrieb vyvolaných internými alebo externými podnetmi. Motivácia nákupného rozhodovania je však osobná. Profesionálny nákupca, je poháňaný motiváciami, ktoré sú vytvorené spoločným záujmom a ambíciami spoločnosti, ktorú zastupuje. Mnoho autorov súhlasí s konštatovaním, že nákupné rozhodovanie individuálneho zákazníka/spotrebitel'a a firiem má rovnakú postupnost', avšak do nákupného procesu firmy často vstupuje diskusia tzv. skupiny rozhodovatel'ov, v ktorej má každý svoje právomoci a zodpovednost' smerom k uskutočnenému nákupu (vid' obr. 2). Najväčší rozdiel medzi procesom nákupu jednotlivca a firiem je formálnost' nákupného procesu firmy a nutnost' širokej akceptovatel'nosti rozhodnutia o nákupe všetkými zapojenými subjektmi. [4] [6]

\footnotetext{
* Ing. Lucia Madleňáková, PhD., Žilinská univerzita v Žiline, Fakulta Prevádzky a ekonomiky dopravy a spojov, Katedra spojov, Univerzitná 1, 01026 Žilina tel.: +421/41/513 3125, fax: +421/41/56 55615 e-mail: Lucia.Madlenakova@,fpedas.uniza.sk
} 

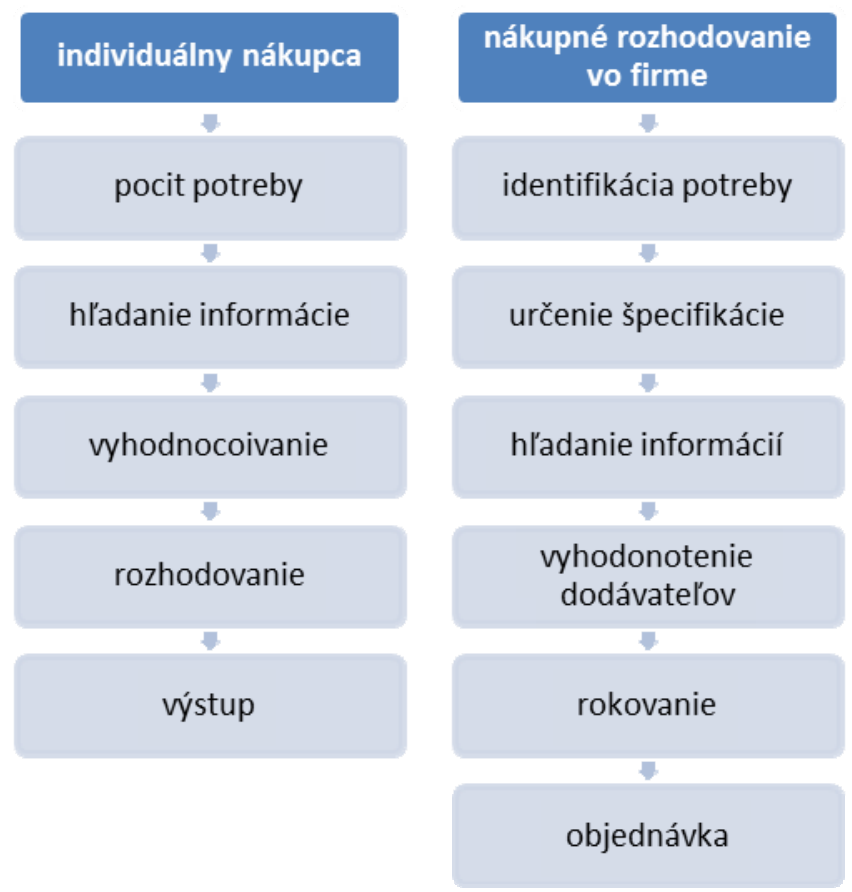

Obrázok 1 Proces nákupného rozhodovania [6]

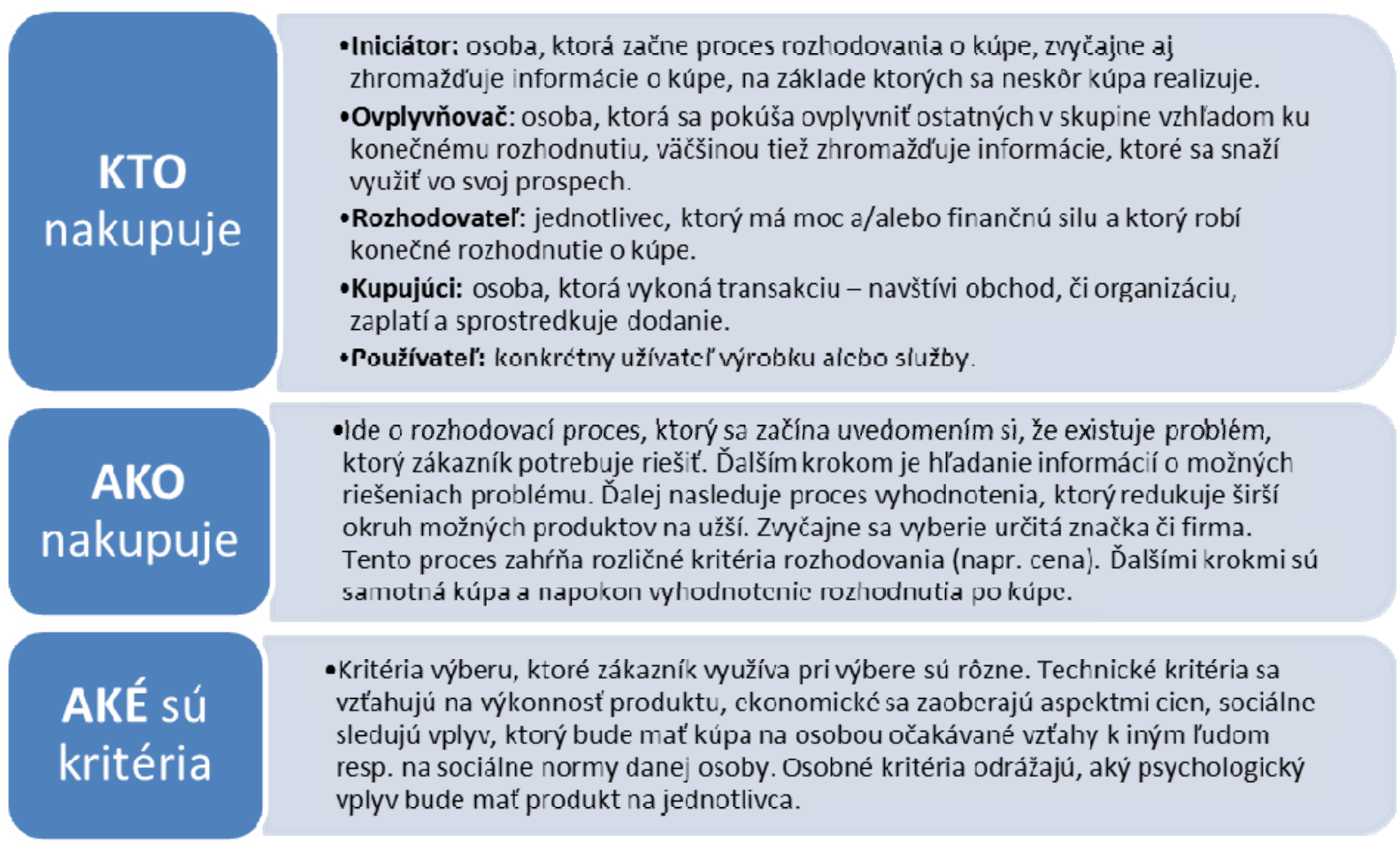

Obrázok 2 Identifikácia nákupného správania sa zákazníka

Zovšeobecnením predchádzajúcich otázok získame základný tematický okruh, ktorý pretransformujeme do ciel'ov marketingového prieskumu. Marketingový prieskum je možné v tomto prípade považovat' za vhodný nástroj na získavanie primárnych informačných zdrojov pre potreby zistenia a identifikovania rozhodovacích kritérií. Vzhl'adom na individuálne priority zákazníkov môžu mat' rozhodovacie kritéria rôznu dôležitost'. Kritéria na základe ktorých sa zákazník rozhoduje o výbere poskytovatel’a služby, či výbere 
konkrétnej služby môžu mat' charakter technicky, to znamená reflektujú činnosti, ktoré realizuje poskytovatel', resp. charakterizujú danú kategóriu produktov a služieb. Môžu to však byt' kritéria, ktoré úzko súvisia s postavením poskytovatel'a/firmy v spoločnosti, ale aj kritéria, ktoré vyjadrujú sociálne postavenie nakupujúceho a jeho osobnost'. [1] [7]

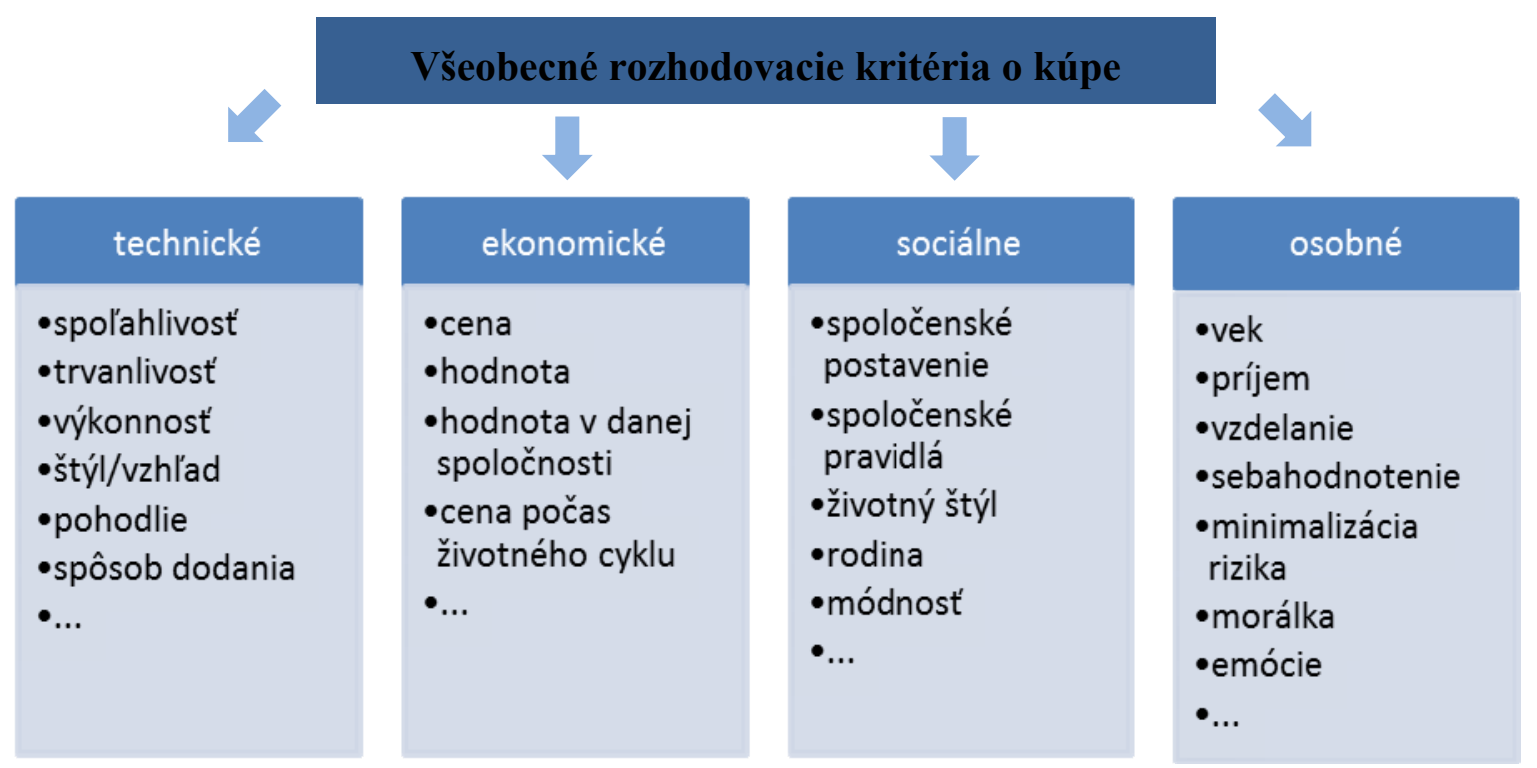

Obrázok 3 Identifikácia nákupného správania sa zákazníka [3][8]

\section{Stanovenie rozhodovacích kritérií pri výbere poskytovatel’a poštových služieb}

Ako bolo v prechádzajúcom texte naznačené niektoré aspekty poskytovaných služieb sú pre zákazníka viac dôležité ako iné. Primárny marketingový prieskum môže pomôct' zistit' čo má pre zákazníka najväčší význam, a čo je dôležité pri jeho nákupnom rozhodovaní. Tieto zistenia následne môžu pôsobit' ako spätná väzba pre poskytovatel'a, ktorý tieto zistenia môže použit' v rámci snahy: ,robit’ čo najlepšie to, čo má pre zákazníka najväčší význam“.

Poštové služby majú na trhu špecifické postavenie vzhl'adom na to, že čast' z nich je poskytovaná v regulovaných podmienkach v kategórií univerzálnej poštovej služby. Avšak portfólio poskytovatel'ov a ich služieb je na trhu rôznorodé a široké. Výber poskytovatel'a, či konkrétnej služby býva často pre zákazníka náročné aj vzhl'adom na časté zahmlievanie skutočnej ponuky.

Kritéria výberu, či porovnávania produktového portfólia u jednotlivých poskytovatel'ov poštových služieb boli stanovené na základe výsledkov marketingového prieskumu, ktorý bol realizovaný dotazníkovou formou. Oslovení boli respondenti v členení na tri kategórie $\mathrm{v}$ závislosti od ich pôsobenia a postavenia na poštovom trhu. Prvou významnou kategóriou sú tzv. experti. Ide o subjekty pôsobiace na úrovní legislatívnych a poradných orgánov (zamestnanci ministerstva, poštového regulačného úradu, poradenské a konzultačné spoločnosti, ...) ale i experti z akademickej sféry. Druhú skupinu respondentov tvorili poskytovatelia poštových služieb a tretiu skupinu tvorili zákazníci - individuálni a firemní.

Prieskumom bolo oslovených 20 expertov, pre potreby spracovania výsledkov bolo použitel'ných 14 dotazníkov. V kategórií poskytovatelia poštových služieb bolo oslovených 56 manažérov pôsobiacich v poštových podnikoch v SR a ČR vrátane poskytovatel'a 
univerzálnej poštovej služby. V prieskume bolo oslovených 300 respondentov v kategórií FO, pričom spracovaných bolo 64\% dotazníkov, v kategórií PO bolo rovnako oslovených 300 respondentov, vhodných pre spracovanie bolo $34 \%$.

Prieskumom boli zist'ované váhy významnosti pre kritéria, ktoré boli stanovené s ohl'adom na portfólio služieb, ktoré je ponúkané poskytovatel'mi na poštovom trhu. Uvedené kritéria by mali pokryt' celú ponuku služieb, pričom respondent v závislosti od svojich skúseností, zvyklostí či preferencií určil váhu významnosti pre každé kritérium v škále od $0-10$. Váha 10 predstavuje najvyššiu dôležitost' daného kritéria pri výbere poskytovatel'a poštovej služby. Výsledky priemerného váhového hodnotenia dôležitosti vybraných kritérií z pohl'adu skúmaných kategórií subjektov sú uvedené v Tabul'ke 1.

Tabul'ka 1 Priemerné váhové hodnotenie významnosti vybraných kritérií

\begin{tabular}{|c|c|c|c|c|c|}
\hline \multirow{3}{*}{ P. č. } & \multirow{3}{*}{ Kritérium } & \multicolumn{4}{|c|}{ Váhové ohodnotenie kritérií (priemer) } \\
\hline & & \multirow{2}{*}{ Experti } & \multirow{2}{*}{ Poskytovatelia } & \multicolumn{2}{|c|}{ Zákazníci } \\
\hline & & & & FO & PO \\
\hline 1. & Produktové portfólio (počet) & 7,00 & 6,23 & 7,08 & 7,48 \\
\hline 2. & Portfólio doplnkových služieb & $\mathbf{1 0 , 0 0}$ & $\mathbf{1 0 , 0 0}$ & 6,76 & 7,04 \\
\hline 3. & Maximálna hmotnost’ zásielky & 7,44 & 8,02 & 6,42 & 6,78 \\
\hline 4. & Lehota dopravy & 10,00 & 9,85 & 8,94 & 8,88 \\
\hline 5. & Doručenie v sobotu & 6,55 & 5,26 & 6,01 & 5,72 \\
\hline 6. & Cena 10 kg zásielky & 5,33 & 5,38 & $\mathbf{9 , 0 3}$ & 8,91 \\
\hline 7. & Pripoistenie zásielky & 8,33 & 8,34 & 6,78 & 6,92 \\
\hline 8. & Colné služby & 8,22 & 8,14 & 7,03 & 6,67 \\
\hline 9. & Balenie & 4,77 & 4,98 & 5,58 & 5,67 \\
\hline 10. & Garancia vrátenia peňazí & 8,22 & 7,98 & 9,15 & 8,67 \\
\hline 11. & Počet kontaktných miest & 8,33 & 7,16 & 7,93 & 8,12 \\
\hline 12. & $\begin{array}{l}\text { Počet krajín, do ktorých je možné } \\
\text { zásielku doručit' }\end{array}$ & 7,77 & 8,95 & 6,11 & 6,10 \\
\hline 13. & Preprava nebezpečného tovaru & 4,22 & 4,35 & 3,46 & 3,59 \\
\hline 14. & Služby eCommerce & 7,88 & 7,56 & 7,46 & 7,42 \\
\hline
\end{tabular}

Zdroj: Vlastné spracovanie podl'a [3]

Zistením váh významnosti jednotlivých kritérií podl’a kategórie respondenta môžeme uvažovat' o subjektívnom a objektívnom hodnotení ponuky poštových služieb. Výsledky prieskumu naznačujú, vakých medziach sa pohybujú preferencie jednotlivých kategórií respondentov, na základe akých kritérií sa rozhoduje zákazník, a na základe akých kritérií zostavuje ponuku poskytovatel'. Prieskum potvrdil, že vnímanie expertov a poskytovatel'ov služieb je z hl'adiska určenia významnosti jednotlivých kritérií zhodné.

Komparáciou objektívneho vnímania, za ktoré je možné považovat' vnímanie expertov v kombinácií s vnímaním poskytovatel'ov poštových služieb so subjektívnym vnímaním, ktoré je reprezentované je možné nájst' konsenzus pre stanovenie optimálnej ponuky služieb, tak aby čo najviac reflektovala požiadavky zákazníkov, ale tiež aby zodpovedala predstavám samotného poskytovatel'a. Ako je z výsledkov zrejmé, z objektívneho hl'adiska, by malo zákazníka zaujímat' pri výbere vhodného poskytovatel'a expresných a kuriérskych služieb predovšetkým portfólio doplnkových služieb. Uvedené kritérium sa vdotazníkovom prieskume umiestnilo s priemerným počtom bodov 10 na prvom mieste (do doplnkových 
služieb patrí napr.: poistenie, colné služby, doručovanie v sobotu...). Je zrejmé, že portfólio doplnkových služieb je považované za prioritu, nakol'ko umožňuje zákazníkovi namodelovat' si službu priamo na mieru a podl'a vlastných potrieb, tzn. že z tohto pohl'adu stráca na význame portfólio základných služieb. Druhé najvýznamnejšie kritérium z pohladu expertov i samotných poskytovatel'ov je lehota prepravy zásielky (počet dní od podania zásielky až po jej dodanie adresátovi), ktorá by mala byt' čo najkratšia. Z pohl'adu subjektívneho hodnotenia je pre zákazníka pri výbere poskytovatel'a rozhodujúca cena zásielky, lehota prepravy a garancia vrátenia peňazí pri nedodržaní poštových či obchodných podmienok.

Na základe zistení, ktoré priniesol marketingový prieskum je vhodné stanovit’ ponuku služieb a namierit' marketingové aktivity poskytovatel'a smerom k určeným požiadavkám zákazníka, samozrejme pri zachovaní základných predstáv poskytovatel'a. Tak ako medzi významnými predstavitel’mi ekonómie a marketingu existuje rozpor či je základom podnikania uspokojenie zákazníka, alebo dosahovanie zisku, rovnaký rozpor existuje aj vo vnímaní existujúcej ponuky a nákupných preferencií zákazníka. Zlatá stredná cesta je teda niekde uprostred medzi subjektívnym a objektívnym vnímaním ponuky služieb.

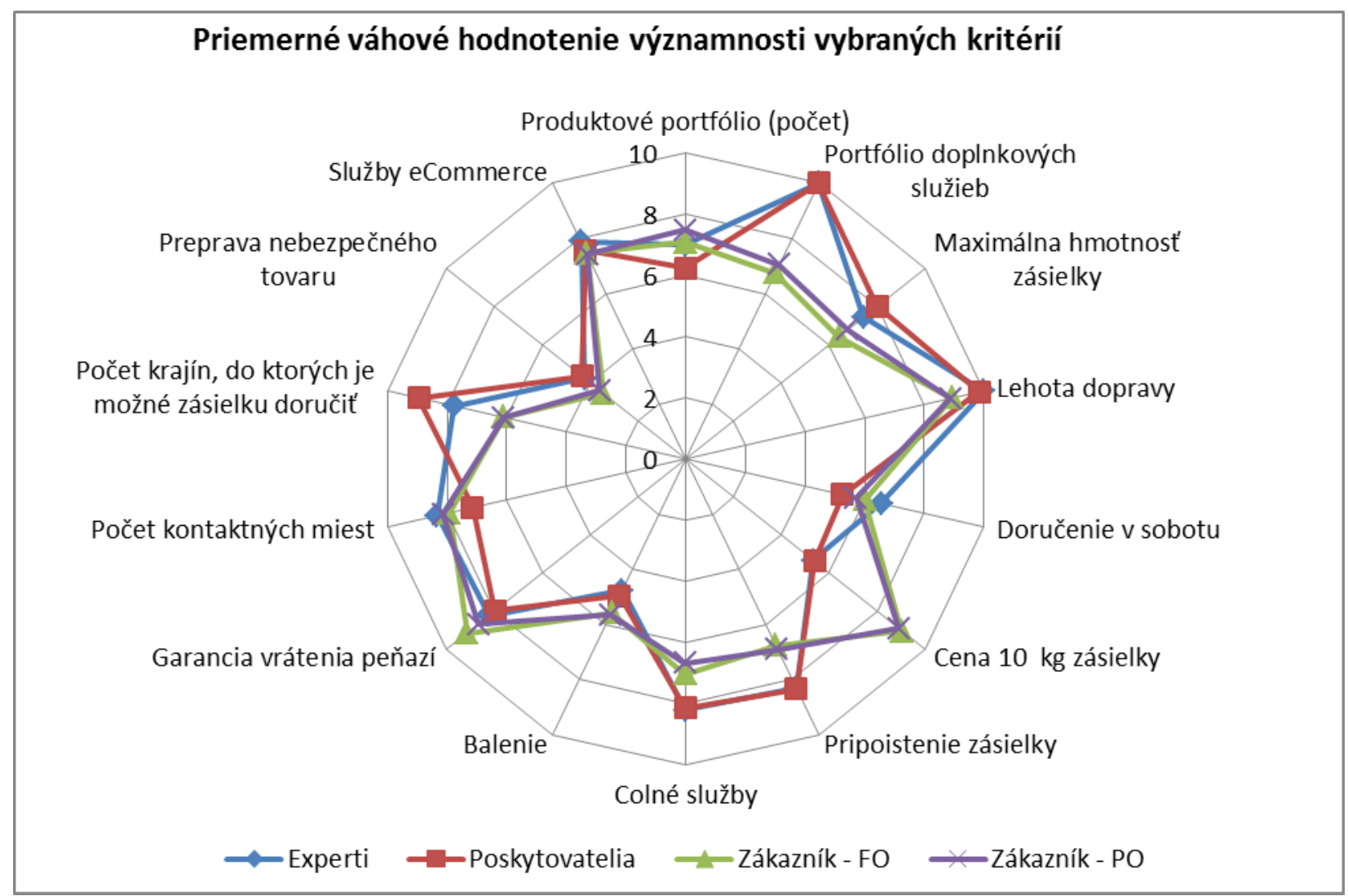

Obrázok 4 priemerné váhové hodnotenie významnosti vybraných kritérií z pohl'adu subjektov pôsobiacich na poštovom trhu

\section{Záver}

Znalost' zákazníckych požiadaviek, preferencií a nákupných zvyklostí je významný aspekt, ktorý vedie poskytovatel'a poštových služieb k úspešnému pôsobeniu na trhu. Prieskum potvrdil, ktoré kritéria sú pre zákazníka významné a ktorých význam je v rozpore s vnímaním poskytovatel'a. Stanovenie optimálnej ponuky, tak aby úplne vyhovovala 
požiadavkám zákazníkov a zároveň aj predstavám poskytovatel’ov je takmer nemožné. Snahou by však malo byt' hl'adanie konsenzu na oboch stranách.

\section{Literatúra}

[1] ČOREJOVÁ, T. A KOLEKTÍV.: Ekonomika sietí. 1. vyd. Žilina: Žilinská univerzita EDIS, 2006. 256 s. ISBN 80-8070-629-8.

[2] DYDŇANSKÝ, P, MADLEŇÁK, R.: Viacdimenzionálne modely portfóliového modelovania CRM hodnotového ret'azca poštového operátora. In: Pošta, Telekomunikácie a Elektronický obchod: elektronický odborný časopis zameraný na problematiku poštových a telekomunikačných podnikov a oblast' elektronického obchodovania. - ISSN 1336-8281. - 2010. - Roč. 5, č. 4 (2010), s. 5-10.

[3] KUBIŠOVÁ I.: Objektívne a subjektívne vnímanie ponuky služieb expresných a kuriérskych spoločností. Diplomová práca 2010, Katedra spojov, FPEDAS, Žilinská univerzita v Žiline 2010

[4] MADLEŇÁK, R., VACULÍK, J.: Elektronické podnikanie: Technológie, aplikácie a formy elektronického podnikania/ - 1. vyd. - Žilina: Žilinská univerzita, 2009. - 232 s., ISBN 978-80-8070-952-5

[5] MADLEŇÁKOVÁ, L.: Komparácia ponuky expresných a kuriérskych služieb. In: IPoCC $=$ International Postal and e-Communications Conference : "Postavení poštovních služeb v moderní komunikační společnosti": Pardubice 16.-17. záŕí 2010: sborník př́spevků mezinárodní konference IPoCC. - [Pardubice]: Institut Jana Pernera, 2010. - ISBN 97880-86530-68-0. - S. 200-205.

[6] MATEIDES, A.: Spokojnost' zákaznika a metódy jej hodnotenia: 1. diel Koncepty a skúsenosti. 1. Vyd. Bratislava: EPOS, 1999, ISBN 80-8057-113-9

[7] ROSTÁŠOVÁ, M., CHRENKOVÁ, A.: Innovative potential of postal operators in logistics = Inovačný potenciál poštových operátorov v oblasti logistiky. In: Logistyka. Systemy transportowe. Bezpieczeństwo w transporcie: LogiTrans: VII konferencja naukowo-techniczna, Szczyrk, 14-16 kwietnia 2010. - Radom: Politechnika Radomska, 2010. - ISBN 978-83-7351-362-4. - S. 315-320.

[8] http://www.podnikajte.sk/prevadzka-firmy/category/marketing/article/zakaznickespravanie.xhtml

\section{Grantová podpora}

5/KS/2011 Všeobecný procesný model základných poštových služieb 